\title{
Biomotor Profile of Taekwondo Athletes Poomsae Male Age Under 14 years in East OKU Regency 2019
}

\author{
Noviria Sukmawati ${ }^{1}$ \\ ${ }^{1}$ Sport Education, Universitas Bina Darma, Jalan Jenderal Ahmad Yani No.3 Palembang \\ Coressponding author email: noviria.sukmawati@binadarma.ac.id
}

\begin{abstract}
The purpose of this study is to find out: Biomotor Profile of Taekwondo Poomsae Athletes of Male Under 14 Years of Age in East Oku Regency in 2019. This research is a survey method, while the techniques and data collection use tests and measurements. The study subjects consisted of 13 people with age categories under 14 years. The results showed the data is based on the $\mathrm{T}$ Score in the category of very less percentage of $7.69 \%$ (1 athlete), in the category of less percentage of $38.46 \%$ ( 5 athletes), in the medium category a percentage of $15.38 \%$ (2 athletes), a good category of percentage of $23.08 \%$ (3 athletes), and very good category with a percentage of $15.38 \%$ ( 2 athletes). Based on the results of the analysis that the biomotor profile of male Poomsae taekwondo athletes based on the average value is included in the medium category, so for the trainers and athletes themselves to add more hours especially to do exercises related to taekwondo biomotor.
\end{abstract}

Keywords: Biomotor, Putera Athlete, Poomsae, Age 14 years

\section{INTRODUCTION}

Taekwondo is a martial arts sport that is rooted in traditional Korean martial arts. Taekwondo has many advantages and not only teaches physical aspects, such as fighting skills, but also strongly emphasizes teaching aspects of mental discipline. taekwondo means the art or method of self-discipline or martial arts that uses the techniques of the feet and bare hands (Yoyok Suryadi, 2002: xv). Taekwondo matches are divided into two numbers, namely Kyourugi number and Poomsae number. Kyorugi numbers are a one-on-one fight in the arena using allowed techniques.

Poomsae has several different types of movements. In poomsae, the direction, sequence, position, eye sight, easel, poom name and screams are all set. In the horses, kicks, as well as doing moves and fights of course a poomsae athlete requires good balance and coordination. Athletes who compete in poomsae matches must have good posture and physical and mental condition when competing. Poomsae has several different types of 
movements. the implementation of a poomsae athlete requires good balance and coordination.

There are several factors that must be possessed by an athlete, including good technical, tactical, physical and psychological abilities. It takes a long time to practice techniques and tactics to make these movements perfect and to be a true reflex when done both during practice and in competition. According to Bompa (1994) in Sukadiyanto (2011: 57) the basic capabilities of a sportsman biomotor include strength, endurance, speed, coordination, and flexibility.

Physical exercise must be understood by all athletes, whether at an early age, senior, junior, or veteran. In addition to physical exercise must be better understood, it must also be formed with the dose of each athlete who has different endurance. Therefore it must be done appropriately in accordance with the basic concepts of developing good and correct physical conditions. An athlete who has good biomotor, will be able to display excellent matches.

Biomotor is the ability of human motion which is influenced by the condition of internal organ systems. The internal organ systems include neuromuscular, respiratory, digestive, blood circulation, energy, bone and joint systems. That is, motion will occur if there is energy available both stored in the muscles and obtained from outside the body through food (Sukadiyanto, 2005: 54). On the basis of this, the researcher considers it important to conduct research that will discuss issues concerning athlete biomotor, with the aim of knowing the biomotor components that exist in Taekwondo athletes male under the age of 14 in East Oku Regency.

The purpose of this study was to determine: Biomotor Profile of Taekwondo Poomsae Athletes of Children Under 14 Years Old in East OKU Regency in 2019. The biomotor component in this study consisted of; speed, leg muscle strength, leg power, height, weight, leg length, endurance, balance. The method used in this study is a survey method, while the techniques and data collection use tests and measurements. The survey method is an investigation conducted to obtain facts from the symptoms that exist and look for deficiencies factually (Suharsimi Arikunto, 2006: 56). In accordance with the problems and research objectives studied, specifically this study wanted to examine how the biomotor profile of Poomsae taekwondo athletes of male under the age of 14 in East Oku Regency.

Biomotor component by the condition of two things, namely: (1) energy fitness (fitness energy), and (2) muscle fitness (muscle fitness). Energy fitness consists of aerobic capacity and anaerobic capacity. When discussing energy, always discussing discussion about 
fitness, about biomotor components, endurance or endurance. Harsono (1988: 176) states that strength is a very important component to improve overall physical condition.

According Suharno (1985: 25) there are three kinds of strength, namely: maximum strength, explosive power, and power endurance (strong and durable). 1). Maximum strength is the ability of muscles in maximum concentration and can fight / hold a maximum load as well. 2). The power of explosive power is the ability of a muscle or a group of muscles to overcome resistance at a high speed in a single motion. 3). Power endurance (strong and durable) is the ability to endure the strength of a muscle to resist high intensity load resistance.

One factor that plays a role in the achievement of the kick is a factor in the physical condition of leg muscle strength. In other words, to reach the kick, there must be an element of physical condition, especially the leg muscle strength that is used to lift the thigh and resist when kicking. This leg muscle strength is used when running, and kicking, with strong leg muscles the kick will get stronger. muscle strength increases according to muscle volume "(Strauss, 1988: 7). Thanks to training and coaching regularly and continuously strength will be obtained, which means someone will be able to utilize in accordance with the desired technical movements.

According to Syaifudin (1996: 60) that the legs consist of upper limbs, namely the groin to the knee, and the lower limbs namely the knee to the ankle. From the description above it can be interpreted that leg muscle strength is a component of physical conditions that concerns the ability to lift or hold the weight of an athlete when using leg muscles or legs. So if someone has more ability and in a relatively short time, it means having good power (Rusli Lutan, 2002: 71).

Suharno (1985: 2) states that one of the optimal achievement factors is body shape, body proportions that are in harmony with the type of exercise that is followed. Height is one of the significant aspects for an athlete to be able to develop his expertise in various sports. Arif Sarifudin and Muhadi (1991: 46) state that people who have a high body posture generally have limbs such as arms and legs that are also long which can affect the angle of view of the blow. A person's ideal body weight is strongly influenced by several factors including: age, sex, physical activity, and heredity.

Leg length as part of body posture has a very close relationship in relation to being a lever when kicking a ball. The limbs as the lower body (lower body) function as a body support. The function of the limbs according to the Anatomy Team of FIK UNY (2003): "Legs according to their function as a means of motion, hold the weight of the upper body, 
can move the body (move), can move the body towards the top and others". Endurance is one of the main biomotor components in every sport.

Components of endurance biomotor are generally used as benchmarks to determine the level of physical fitness (physical fitness) sportsman. According Sukadiyanto (2005: 57) understanding of endurance in terms of muscle work is the ability to work muscles or a group in a certain period of time, while the understanding of endurance of the energy system is the ability to work organs in a certain period of time. Based on these two meanings, endurance is defined as the ability of organs to fight fatigue during activities or work.

According to Fox (1992) adding factors that influence endurance training are intensity, frequency, duration of exercise, heredity, age and gender. Balance is the ability to maintain proper posture when doing movements. Depending on the ability of integration between the sense of sight, the center of balance (the semi-lunal canal) and receptors in the muscles (Ministry of National Education, 2000: 57). According to Cureton, quoted by Toho and Gusril (2004: 51), states that the main physical condition functions of motor skills are to develop the abilities and abilities of each individual that is useful to enhance work power. By having good motor skills, each individual has a foundation for mastering specific motor skills tasks.

Psychomotor skills related to correct motion, speed of movement according to the objectives to be achieved, as well as minimal use of energy with the achievement of maximum results. From the description above, it can be concluded by researchers that good motor skills and physical conditions have important functions and roles in the process of increasing peak performance in sports.

\section{METHOD}

The survey method is an investigation conducted to obtain facts from the symptoms that exist and look for deficiencies factually (Arikunto, 2006). In accordance with the problems and research objectives studied, specifically this study wanted to examine how the biomotor profile of Poomsae taekwondo athletes of male under the age of 14 in East Oku Regency.

The instrument is a measuring tool used to obtain quantitative information about variations in the characteristics of variables as a whole (Ibn Hajar, 1999: 160). The data of this research are biomotor profiles of taekwondo athletes consisting of; (1) speed measured using a 60 meter running test in seconds, (2) leg muscle strength measured using a leg and back dynamometer in kilograms, (3) leg power measured using a vertical jump test with 
centimeters, (4) height measured using a stadiometer in centimeters, (5) body weight measured using a stepper scale in kilograms, (6) leg length using a meter in centimeters (7) aerobic endurance is measured using a multistage fitnest test in $\mathrm{ml} / \mathrm{kg} / \mathrm{min}$, (8) the balance is measured using the Balance Measuring Instrument in units of seconds, all data then the data is converted into a T-score and added up.

\section{RESULTS}

The detailed description of each biomotor profile variable for male taekwondo Poomsae athletes under 14 years of age in East OKU Regency is as follows:

Table 1. Frequency Distribution

\begin{tabular}{llrll}
\hline No & \multicolumn{1}{c}{ Tes } & \multicolumn{1}{c}{ Persentase } & \multicolumn{1}{c}{ Kategori } \\
\hline 1 & Running Speed of & 60 & $84.62 \%$. & very well \\
& Meters & & & \\
2 & Leg Muscle Strength & & $38.46 \%$. & very well \\
3 & Aerobic Endurance & $69.23 \%$. & is on \\
4 & Power Legs & $30.77 \%$. & less \\
5 & Balance & $38.46 \%$. & less \\
6 & Leg Length & $38.46 \%$. & less \\
7 & Height & 130.07 & is on \\
8 & Weight & $61.54 \%$. & very less \\
\hline
\end{tabular}

The results of the calculation of biomotor profile data for Poomsae taekwondo athletes of children under the age of 14 in East Oku Regency. When displayed in the form of a bar chart, the biomotor profile data of male taekwondo poomsae athletes under the age of 14 in East Oku district based on the T Score, appear as follows:

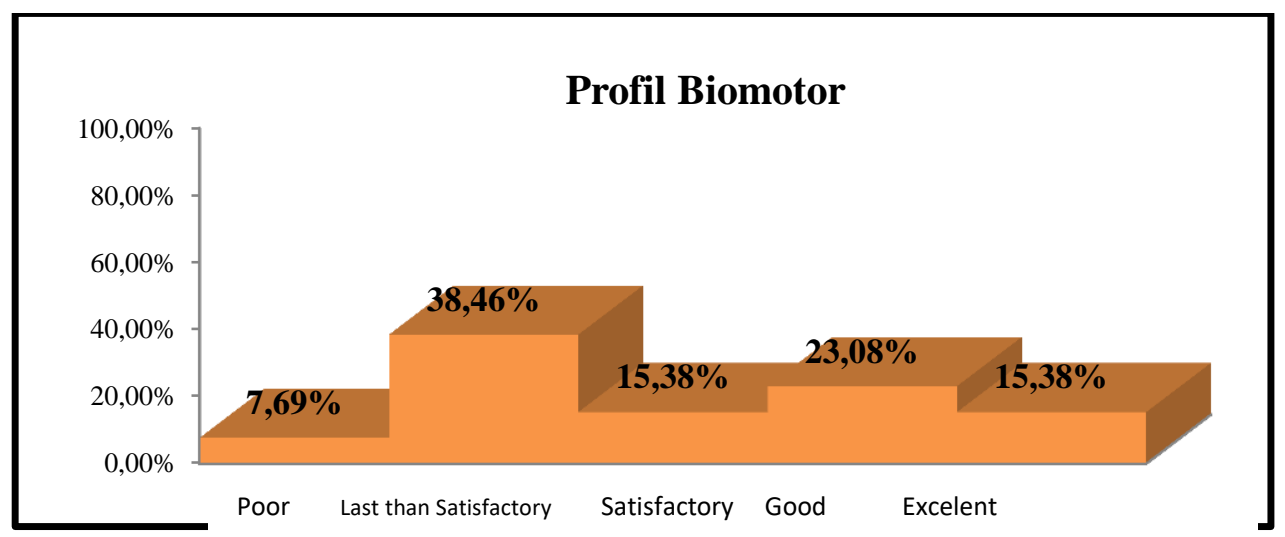

Figure 1. Diagram of the Biomotor Profile of Taekwondo Poomsae Athletes of Children Under 14 Years of Age in East Oku Regency 
Based on the table and graph above, it can be seen that the biomotor profile of male taekwondo Poomsae athletes under the age of 14 in East Oku Regency in 2019 based on the T Score is at:

Table 2. Biomotor profile of male taekwondo Poomsae athletes under the age of 14 years in East Oku regency based on T Score

\begin{tabular}{clcl}
\hline No & \multicolumn{1}{c}{ Category } & Persentase & Total \\
\hline 1 & very well & $15.38 \%$ & 2 athlete \\
2 & Well & $23.08 \%$ & 3 athlete \\
3 & is on & $15.38 \%$ & 2 athlete \\
4 & Less & $38.46 \%$ & 5 athlete \\
5 & very less & $7.69 \%$ & 1 athlete \\
\hline
\end{tabular}

Biomotor profile of male taekwondo Poomsae athletes under the age of 14 years in East Oku regency based on T Score was in the category of very poor percentage of $7.69 \%$ (1 athlete), in the category of percentage less than $38.46 \%$ (5 athletes), in the medium category the percentage was $15.38 \%$ ( 2 athletes), good category percentage of $23.08 \%$ ( 3 athletes), and very good category with percentage of $15.38 \%$ ( 2 athletes). Based on the results of the analysis showed that the biomotor profile of male taekwondo athletes Poomsae under the age of 14 years in East Oku Regency based on the average value included in the medium category.

\section{DISCUSSION}

This study aims to determine the biomotor profile of Poomsae taekwondo athletes of children under the age of 14 in East Oku Regency in 2019 in this study consisting of; (1) speed measured using a 60 meter running test in seconds, (2) leg muscle strength measured using a leg and back dynamometer in kilograms, (3) leg power measured using a vertical jump test with centimeters, (4) height measured using a stadiometer in centimeters, (5) body weight measured using a stepper scale in kilograms, (6) leg length using an anthropometer in centimeters (7) aerobic endurance is measured using a multistage fitnest test in $\mathrm{ml} / \mathrm{kg} / \mathrm{min}$, (8) the balance is measured using the Balance Measuring Instrument in units of seconds, all data then the data is converted into a T-score and added up.

Biomotor profile of male Poomsae taekwondo athletes under the age of 14 in East Oku Regency in 2019, as follows: 1. Based on the average value, which is 6.88 , the 60 meter running speed of Poomsae male taekwondo athletes under 14 years old in East Oku Regency is in the excellent category. 2. Based on the average value, which is 137.19 , the leg muscle 
strength of Poomsae male taekwondo athletes under 14 years old in East Oku Regency is in the good category. 3. Based on the average value, which is 34.45 , the aerobic endurance of Poomsae male taekwondo athletes under 14 years old in East Oku Regency is in the medium category.

4. Based on the average value, which is 36.77 , the limb power of Poomsae taekwondo athlete under the age of 14 in East Oku Regency is in the medium category. 5. Based on the average value, which is 24.69 , the balance of male Poomsae taekwondo athletes under 14 years old in East Oku Regency is in the poor category. 6. Based on the average value, which is 34.15, the limb length of Poomsae male taekwondo athletes under 14 years old in East Oku Regency is in the less category. 7. Based on the average value, which is 130.07 , the height of the male athlete Poomsae taekwondo under the age of 14 in East Oku Regency is in the medium category. 8. Based on the average value, which is 30.11 , the body weight of male taekwondo Poomsae athletes under 14 years old in East Oku Regency is in the poor category.

Biomotor profile of male taekwondo Poomsae athletes under the age of 14 in Sleman Regency in 2013 based on the T Score was in the category of very poor percentage of $7.69 \%$ ( 1 athlete), in the category of less percentage of $38.46 \%$ ( 5 athletes), in the medium category the percentage of $15.38 \%$ ( 2 athletes), good category percentage of $23.08 \%$ ( 3 athletes), and very good category with a percentage of $15.38 \%$ ( 2 athletes). Based on the results of the analysis shows that the biomotor profile of Poomsae taekwondo athletes of children under 14 years old in East Oku Regency based on the average value is included in the medium category, so for the trainers and athletes themselves to add more hours especially to do exercises related to biomotor Taekwondo.

The goal of sports activities possessed by every athlete becomes a separate demands to be able to encourage the achievement of these objectives. For athleteswho want to achieve the highest achievement, the athlete must be able to practice hardly. Programmed and regular practice will contribute which is positive towards the development of skills and abilities owned. This is because the development of biomotor components cannot obtained just like that but requires a strict exercise program. Situation this requires good cooperation from coaches and athletes to be able to run an exercise program to the maximum by having a target maximum.

Taekwondo is a martial arts sport that has the ability to develop several biomotor components which is good in the human body. Taekwondo sports so far are competed is a 
fight, and as we know, if we are fighting will definitely require, muscle strength, speed, power, balance, flexibility, endurance and movement skills (devi, 2005). The biomotor components are absolutely needed intaekwondo fight.

\section{CONCLUSION}

Biomotor profile for male taekwondo athletes Poomsae under the age of 14 in East Oku Regency is included in the medium category, so that the trainers and athletes themselves should add more hours especially to do exercises related to taekwondo biomotor. A good biomotor has several advantages, including athletes who are able and easy to learn skills that are relatively difficult, do not get tired easily when participating in training or competition, the training program can be completed without many obstacles and can complete strenuous training. Biomotor is really needed by an athlete, because without the support of excellent physical condition, the peak achievement will experience many obstacles and it is impossible to achieve high achievements.

\section{REFERENCES}

Aip Syarifuddin dan Muhadi. (1991). Pendidikan Jasmani. Jakarta: Depdikbud. Dirjendikti. Proyek Pembinaan Tenaga Kependidikan.

Devi Tirtawirya. (2005). Perkembangan Dan Peranan Taekwondo Dalam Pembinaan Manusia Indonesia. Jurnal Olahraga Prestasi Volume 1, Nomor 2 : 195 - 21.

Fox L, Bowel RW, and Foss Mc. (1993). The Physiological Basis For Exercise on Sport: Brown and Bench mark Publisher.

Harsono, (1988). Coaching dan Aspek-aspek Psikologis Dalam Coaching. Jakarta: CV. Tambak Kusuma.

Ibnu Hajar. (1999). Dasar-Dasar Metodologi Penelitian Kuantitatif dalam Pendidikan. Jakarta: PT Raya Grafindo Persada.

Rusli Lutan. (2002). Pengukuran dan Evaluasi Penjaskes. Jakarta: Departemen Pendidikan Nasional.

Straus, R.H,. (1988). Sport Medicine. Philadelphia: WB Sunders Company.

Sajoto. 1988. Pembinaan Kondisi Fisik Dalam Olahraga. Departemen Pendidikan dan Kebudayaan Direktorat Jenderal Pendidikan Tinggi Proyek Pengadaan Buku pada Lembaga Pengembangan Tenaga Pendidikan. Jakarta. 
Suharsimi Arikunto. (2006). Prosedur Penelitian Suatu Pendekatan Praktik. Jakarta: PT. Rineka Cipta.

Suharno. (1985). Ilmu Kepelatihan Olahraga. Yogyakarta: FPOK IKIP Yogyakarta.

Sukadiyanto. (2011). Pengantar Terori dan Metodologi melatih Fisik. Bandung: CV Lubuk Agung

Sukadiyanto. (2005). Pengantar Teori Dan Melatih Fisik. Yogyakarta: FIK Universitas Negeri Yogyakarta.

Tim Anatomi. (2003). Diktat Anatomi Manusia. Yogyakarta: Laboratorium Anatomi FIK UNY.

V. Yoyok Suryadi. (2002). “Taekwondo Poomse Taeguek”. Jakarta : PT Gramedia Pustaka Utama. 